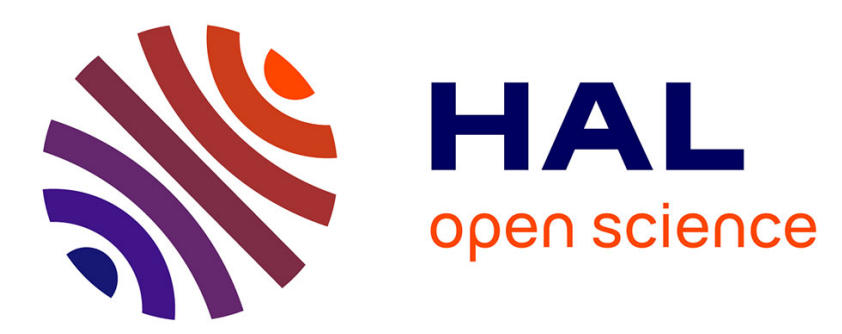

\title{
Effect of silicon content in steel and oxidation temperature on scale growth and morphology
}

Amine Alaoui Mouayd, Alexey Koltsov, Eliane Sutter, Bernard Tribollet

\section{To cite this version:}

Amine Alaoui Mouayd, Alexey Koltsov, Eliane Sutter, Bernard Tribollet. Effect of silicon content in steel and oxidation temperature on scale growth and morphology. Materials Chemistry and Physics, 2014, 143, pp.996-1004. 10.1016/j.matchemphys.2013.10.037 . hal-00943404

\section{HAL Id: hal-00943404 https://hal.sorbonne-universite.fr/hal-00943404}

Submitted on 23 Oct 2014

HAL is a multi-disciplinary open access archive for the deposit and dissemination of scientific research documents, whether they are published or not. The documents may come from teaching and research institutions in France or abroad, or from public or private research centers.
L'archive ouverte pluridisciplinaire HAL, est destinée au dépôt et à la diffusion de documents scientifiques de niveau recherche, publiés ou non, émanant des établissements d'enseignement et de recherche français ou étrangers, des laboratoires publics ou privés. 


\title{
Effect of silicon content in steel and oxidation temperature on scale growth and morphology
}

\author{
$\underline{\text { Amine ALAOUI MOUAYD }}^{\mathrm{a}, \mathrm{b}, \mathrm{c}}$, Alexey KOLTSOV ${ }^{\mathrm{c}}$, Eliane SUTTER ${ }^{\mathrm{a}, \mathrm{b}}$, Bernard \\ TRIBOLLET $^{\mathrm{a}, \mathrm{b}}$,
}

${ }^{a}$ CNRS, UPR15, Laboratoire Interfaces et Systèmes Electrochimiques, F-75005 Paris, France.

${ }^{\mathrm{b}}$ UPMC Univ Paris 06, UPR15, LISE, 4 place Jussieu, F-75005 Paris, France

${ }^{\mathrm{c}}$ ArcelorMittal Maizières Research, voie Romaine, F-57280, Maizières-lès-Metz, France

\section{Corresponding author:}

Amine ALAOUI MOUAYD

LISE, UPMC, 4 place Jussieu, 75005 Paris, France

e-mail: amine.alaoui_mouayd@upmc.fr

Tel: $00 \overline{3314427432}$

\begin{abstract}
The effect of high silicon content in steel, $1.6 \mathrm{wt} . \% \mathrm{Si}$ and $3.2 \mathrm{wt} . \% \mathrm{Si}$, and high oxidation temperatures $\left(850-1200^{\circ} \mathrm{C}\right)$ on scale growth rate and morphology were investigated. Steels were oxidized in a $15 \%$ humid air with short isothermal oxidation times $(15 \mathrm{~min})$. The scale growth rate of non alloyed steels follows parabolic law with time; it is an iron diffusion controlled oxidation. The presence of silicon delays scale growth by forming a silica $\mathrm{SiO}_{2}$ barrier layer at the scale/metal interface, this effect is more important for steels containing 3.2 wt.\% Si and induces a discontinuous scale. Silicon oxides are concentrated at the scale/metal interface; their morphology depends on oxidation temperature. For temperatures lower than $950^{\circ} \mathrm{C}$, silica is formed. Between $950^{\circ} \mathrm{C}$ and $1150^{\circ} \mathrm{C}$, fayalite $\left(\mathrm{Fe}_{2} \mathrm{SiO}_{4}\right)$ grains appear in the wüstite matrix close to the scale/metal interface. For temperatures higher than $1177^{\circ} \mathrm{C}$, a fayalite-wüstite eutectic is formed; this molten phase favors iron diffusion leading to high scale growth. After cooling, a continuous fayalite layer with small wüstite grains is obtained at the scale/steel interface.
\end{abstract}

\section{Key Words:}

alloys

oxidation

thermogravimetric analysis (TGA)

Raman spectroscopy and scattering

\section{Highlights:}

- A passivation period appears during oxidation of Silicon steels at temperatures lower than $1177^{\circ} \mathrm{C}$ due to silica formation.

- Silicon oxides concentrate at metal scale interface, their morphology depends on oxidation temperature.

-High silicon content leads to silica formation and long passivation of oxidation at temperatures lower than $1177^{\circ} \mathrm{C}$.

- Molten fayalite-wüstite eutectic at high temperatures enhances iron diffusion and cancels oxidation passivation. 


\section{Introduction}

In the hot strip mill process, steel surface is in contact with humid air at high temperatures: from nearly $1200^{\circ} \mathrm{C}$ (reheating furnace) to nearly $700^{\circ} \mathrm{C}$ (coiling). At these conditions an oxide layer called commonly "scale" is formed. It is usually removed by dissolution in an acid bath to recover a clean steel surface. For non alloyed steels, scale is mainly composed of iron oxides and dissolved easily in pickling baths.

Some alloying elements such as $\mathrm{Si}, \mathrm{Mn}, \mathrm{Al}$ are added to steel to reach high level of mechanical properties like elasticity limit, strain strength, elongation, formability and crash worthiness. These elements segregate at high temperatures towards the scale/metal interface forming mixed oxides for silicon and aluminium or solid solutions in scale for Mn [1-3]. The presence of these oxides in scale and at the steel/metal interface affects the pickling efficiency.

In this study, the focus is put on silicon effect on scale formation kinetics and chemistry during oxidation at hot strip mill temperatures. Silicon is present in Alloyed High Strength Steels (AHSS) to improve their mechanical and corrosion resistance, as well as in electrical steels for improving the electrical resistivity, which is an important property for applications as the core material of electro-magnetic devices such as motors [4-6].

The elaboration of new silicon alloyed steel grades and the difficulties to pickle them triggered many recent studies on the effect of silicon on oxidation kinetics and final scale morphology. Some of these studies proposed some oxidation mechanisms for silicon alloyed samples but were limited to medium silicon alloyed grades and did not correspond completely to the Hot Strip Mill conditions [7-11].

According to Atkinson [12] and Adachi et al. [13] silicon contained in steel is first oxidized into silica which forms an interfacial sub-layer between wüstite and steel. The internal oxidation of steel can be also observed (oxide particles inside the steel), especially for the steel containing more than $0.3 \mathrm{wt} . \% \mathrm{Si}$. Genève [14] pointed out that scale adhesion is lower on $\mathrm{Si}$ steels than in that of $\mathrm{FeO}$ on pure $\mathrm{Fe}$. On the contrary, adhesion between silica or fayalite and the substrate is strong: leading to an increased difficulty to remove scale containing silicate phases during pickling. Above $1177^{\circ} \mathrm{C}, \mathrm{FeO}-\mathrm{Fe}_{2} \mathrm{SiO}_{4}$ [15] eutectic melts and infiltrates scale and steel grain boundaries. The penetration depth into the scale increases with the Si content, while that into the substrate varies slightly. The presence of liquid phase improves the scale adhesion for steels containing less than $0.5 \mathrm{wt} . \% \mathrm{Si}$, but for higher $\mathrm{Si}$ contents (up to $1.5 \mathrm{wt} . \%$ ) the tendency is inversed.

In our study, high temperature and humidity conditions corresponding to those in the hot strip mill were applied on a medium and a highly silicon alloyed steel grades to determine the silicon effect on scale formation kinetics and mechanism. The chemistry and morphology of the resulting scale as well as the oxidation mechanism are demonstrated by crossing different characterization methods.

\section{Experimental implementation}

\subsection{Samples Elaboration:}

Samples of steel with different grades were elaborated in a $1 \mathrm{~kg}$ furnace where a bloc of non alloyed steel melts and adequate masses of alloying elements were added to create the desired grades. After each addition, pencils were extracted with depressurized glass tubes. The pencils have a cylindrical form with a $4 \mathrm{~mm}$ diameter and 120 to $150 \mathrm{~mm}$ length. The final samples form is a cylinder of 5 to $10 \mathrm{~mm}$ length with a hook welded on its top disc for suspension in a thermo-gravimetric analyser, the studied surface is then the cylinder's bottom 
disc. Grades with silicon contents 0.02 wt.\%Si (Si00), 1.6 wt.\%Si (Si16) and 3.2 wt.\%Si (Si32) were targeted, their chemical composition is given in Table 1.

\subsection{Oxidation tests:}

The oxidation tests were conducted in a Linseis ${ }^{\circledR}$ Thermo-Gravimetric Analyser (TGA). The bottom disc surface of all samples was ground with a SiC-paper up to grade 800, cleaned in ethanol and then dried in air before oxidation tests. The mass change was recorded continuously (1 point/second) during the entire thermal cycle. The sample was heated in a Nitrogen atmosphere at a rate of $40^{\circ} \mathrm{C} \mathrm{min}^{-1}$ and $5^{\circ} \mathrm{C} \mathrm{min}{ }^{-1}$ for the last $50^{\circ} \mathrm{C}$ to avoid overheating once the desired oxidation temperature was reached. All oxidations were isothermal at temperature range $850-1200^{\circ} \mathrm{C}$, in a $15 \%$ humid air during 15 minutes. Some additional experiments have been performed at lower duration for characterization purposes. After the test, the TGA chamber was cooled in a $\mathrm{N}_{2}$ atmosphere down to room temperature with a $40^{\circ} \mathrm{C}$ $\min ^{-1}$ rate.

\subsection{Scale characterisation:}

After oxidation in TGA, the samples were moulded in a cold resin and ground with $\mathrm{SiC}$-papers up to grade 4000 to obtain cross-sections micrographs. Scale phases were observed with optical microscopy and scanning electrons microscopy. Phase nature was identified using Raman spectroscopy analyses and estimation of elements content given by energy dispersive spectroscopy (EDS). Some samples were analysed by X-rays photoelectron spectroscopy (XPS) and Auger-FEG. The XPS setup used for characterizations was a PerkinElmer PHI 5500 with monochromatic Al Ka X-ray source of $187 \mathrm{eV}$ (for survey spectra) and $11 \mathrm{eV}$ (for high resolution spectra) pass energies of the analyzer. XPS characterizations showed depth resolution of $10 \mathrm{~nm}$; lateral resolution chosen for the analyses was of $0.8 \times 2$ $\mathrm{mm}^{2}$. Auger-FEG characterizations were performed with a Jeol Jamp 9500F device. Analyses were done at an acceleration voltage of $15 \mathrm{kV}$, a beam current of $1 \times 10^{-8} \mathrm{~A}$ and a sample tilt of $0^{\circ}$.

\section{Results and discussion:}

\subsection{Scale growth Kinetics}

The mass gain per surface unit $(\Delta \mathrm{m} / \mathrm{S})$ of non-alloyed sample Si00 during oxidation in $15 \%$ humid air, at temperatures $900-1200^{\circ} \mathrm{C}$ is reported in Fig. 1. For non-alloyed sample $\mathrm{Si00}$ at all oxidation temperatures, scale growth first follows a linear law (1) then a parabolic law (2).

Mass gain laws can be described by following formulas:

- First linear step:

$$
(\Delta m / S)=k_{l} \cdot t
$$

- Parabolic step:

$$
(\Delta m / S)^{n}=k_{p} . t
$$

With

$$
\mathrm{n}>1 \text { and } k_{i}=k_{i 0} \cdot e^{-\frac{Q}{R T}}
$$


According to Arrhenius law (3) $k_{i}$ is the kinetic constant ( $k_{l}$ for the linear part and $k_{p}$ for the parabolic part), $Q$ is the activation energy and $R$ the gas constant. The value of $n$ in the parabolic law varies from 1 to 2 during the linear-parabolic transition period before being fixed to 2 after few minutes of oxidation.

The effect of intermediate content of silicon on mass gain during oxidation of Sil6 in the same temperature range $900-1200^{\circ} \mathrm{C}$ is shown in Fig. 2. For oxidation temperatures lower than $1100^{\circ} \mathrm{C}$, the mass gain follows the initial linear law but for a very short time, less than 10 seconds, then stagnates during 30 seconds to 2 minutes depending on oxidation temperature. After this passivation period, the scale growth follows a parabolic law at all temperatures. The mass gain of Sil6 at $1200^{\circ} \mathrm{C}$ shows higher values compared to lower temperatures. The curve profile is also different; the passivation period has completely disappeared and the linear then the parabolic steps similar to those of Si00 are observed.

In Fig. 3, the high silicon content of Si32 induces much longer passivation periods especially at $1000^{\circ} \mathrm{C}$ and $1100^{\circ} \mathrm{C}$ in comparison with Sil6 (Figs $3 \mathrm{~b}$ and $2 \mathrm{~b}$ ). This passivation effect disappears at $1200^{\circ} \mathrm{C}$ (Figure 3a).

Kinetics parameters for linear and parabolic parts of oxidation of Si00 were evaluated at the four tested temperatures. They are reported in Table $2\left(k_{l}\right.$ and $k_{p}$ for the different oxidation temperatures and silicon contents). On an Arrhenius diagram representing the variation of the linear and parabolic kinetics constants as a function of $(1 / \mathrm{T})$ on a logarithmic scale, the slope of the regression straight line gives an estimation of the activation energy $Q$ for the linear and parabolic steps of oxidation: $Q_{l}=54 \mathrm{~kJ} \mathrm{~mol}^{-1}$ and $Q_{p}=144 \mathrm{~kJ} \mathrm{~mol}^{-1}$, as well as the origin of the kinetics constants $k_{l 0}=2.4 \times 10^{3} \mathrm{mg} \mathrm{cm}^{-2} \mathrm{~min}^{-1}$ and $k_{p 0}=3.04 \times 10^{7} \mathrm{mg}$ $\mathrm{cm}^{-2} \mathrm{~min}^{-1}$. The higher activation energy of the parabolic step confirms the decrease of reactivity of the growing scale in comparison with steel surface at the beginning of oxidation.

Linear and parabolic kinetics constants, as well as the resulting mass gain values during oxidation in $15 \%$ humid air for non alloyed steels, increase with temperature.

The first linear step, which takes some seconds, corresponds to the formation of continuous iron oxide layer (scale) on the steel surface, and then the scale growth is decelerated in a transition regime to follow a parabolic law. At the beginning of oxidation, both iron at steel surface and oxygen are abundant and reacts with low activation energy, the reaction is controlled by interfacial steps only [3, 16]. After formation of the first wüstite layer, iron must diffuse through vacancies and becomes the limiting reactant of an oxidation happening at scale surface. In the parabolic growth period, the oxidation reaction is controlled by the diffusion of $\mathrm{Fe}^{2+}$ through vacancies of the growing wüstite layer [17-19].

Oxidation kinetics parameters of Si16 are reported in Table 2. The intermediate content of silicon reduces the initial linear constants values compared to Si00 at the same oxidation temperatures except for $1200^{\circ} \mathrm{C}$ where a higher $k_{l}$ is observed (Table 2a). The post passivation period kinetics constant $k_{p}$ increases with increasing oxidation temperatures (Table 2b).

The oxidation kinetics parameters $k_{l}$ and especially $k_{p}$ for Si32 are significantly affected by the long passivation period since their values are much lower compared to Si16 at $1000^{\circ} \mathrm{C}$ and $1100^{\circ} \mathrm{C}$. However, higher $k_{l}$ and $k_{p}$ values are observed for oxidation at $1200^{\circ} \mathrm{C}$.

In Fig. 4 the comparison of the final mass gain after 15 minutes of oxidation for all tests, confirms the switching effect of increasing silicon content for temperatures higher than $1100^{\circ} \mathrm{C}$ where the passivation is replaced by an acceleration of oxidation.

The higher concentration of silicon and its random distribution on steel surface and the short oxidation time compared with experiments found in literature $[20,21]$ can explain the random kinetics values in our case and the difficulty to calculate the activation energy.

As it will be demonstrated in the Section 3.2., the passivation period is due to the formation of a thin silica layer as $\mathrm{Si}$ is more prone to oxidation than iron. This layer 
dramatically slows down the diffusion of $\mathrm{Fe}^{2+}$ towards the surface in contact with the oxidizing atmosphere $[9,22]$. This effect increases with silicon content and temperatures between $950^{\circ} \mathrm{C}$ and $1100^{\circ} \mathrm{C}$ favourable for silica. The resulting scale is thin but rich in $\mathrm{SiO}_{2}$.

The oxidation passivation effect disappears at $1200^{\circ} \mathrm{C}$, this is due to the formation of a Wüstite-Fayalite eutectic at temperatures higher than $1177^{\circ} \mathrm{C}$ [15]. This melting phase favours the diffusion of iron ions to the external oxidizing atmosphere and oxygen to the interface, accelerating the external and internal oxidation rates [20]. The diffusion coefficients of iron and oxygen in the liquid oxides $\left(\mathrm{D}_{\mathrm{Fe}}\right.$ in molten $\mathrm{FeO}-\mathrm{SiO}_{2}$ around $8 \times 10^{-5} \mathrm{~cm}^{2} \mathrm{~s}^{-1}$ at $1250^{\circ} \mathrm{C}$ [23], $\mathrm{D}_{\mathrm{O}}\left(\right.$ or $\mathrm{D}_{\mathrm{Fe}}$ ) in liquid iron oxides around $2.5 \times 10^{-3} \mathrm{~cm}^{2} \mathrm{~s}^{-1}$ at $1400^{\circ} \mathrm{C}$ and $3 \times 10^{-3} \mathrm{~cm}^{2} \mathrm{~s}^{-1}$ at $\left.1615^{\circ} \mathrm{C}[24,25]\right)$ are higher by several orders of magnitude than the diffusion coefficients in the solid silicon oxide $\left(D_{\mathrm{Fe}}\right.$ in silica around $1.5 \times 10^{-10} \mathrm{~cm}^{2} \mathrm{~s}^{-1}$ at $\left.1100^{\circ} \mathrm{C}[20,26]\right)$.

\subsection{Scale Characterization:}

In the oxidation conditions of this study, the resulting non alloyed steel (Si00) scale is homogenous and essentially composed of a wüstite layer covered by a magnetite thinner layer (Fig. 5a). Below $570^{\circ} \mathrm{C}$ wüstite is unstable: it transforms into iron and magnetite eutectoid. However, this transformation enables very low cooling rates. Considering a post oxidation cooling speed of about $40{ }^{\circ} \mathrm{C} \mathrm{min}-1$ in all experiments of this study, the wüstite transformation can be assumed for low part of scale volume, which is not clearly visible on SEM even at high magnification $[27,28]$.

EDS analyses revealed a slight difference in the oxygen and iron ratio between internal and external scale layers. The external layer composition is close to $\mathrm{Fe}_{3} \mathrm{O}_{4}$ and the internal one close to $\mathrm{FeO}$ (Table 3).

On the scale top surface, Raman analysis reveals the presence of a hematite layer with intense peaks at $220 \mathrm{~cm}^{-1}$ and $290 \mathrm{~cm}^{-1}$ and $410 \mathrm{~cm}^{-1}$, as well as small peaks at 500 and 610 $\mathrm{cm}^{-1}$ (Fig 5b). This layer is very thin and not visible on SEM micrograph of the sample crosssection (Fig. 5a). Raman characterizations performed on cross-section do not distinguish clearly magnetite from wüstite. The Raman spectrum provided on external layer corresponds well to the spectrum of magnetite $\left(\mathrm{Fe}_{3} \mathrm{O}_{4}\right)$ with characteristic peaks at $310 \mathrm{~cm}^{-1}, 540 \mathrm{~cm}^{-1}$ and $670 \mathrm{~cm}^{-1}$ (Fig. 5b). Wüstite phase (FeO) is cubic and should not be visible on Raman spectra. However, a peak at $660-670 \mathrm{~cm}^{-1}$ was observed during Raman analyses on the internal layer (Fig. 5b) [29, 30]. This peak could be attributed to the presence of vacancies in the wüstite microstructure (wüstite $\mathrm{Fe}_{1-\mathrm{x}} \mathrm{O}$ with relatively large $x$ variation according to the phase diagram [27]) or partial wüstite transformation during cooling into $\mathrm{Fe}+\mathrm{Fe}_{3} \mathrm{O}_{4}$ eutectoid (presence of magnetite areas).

The presence of the two external layers with iron oxidation degrees higher than that of wüstite comes from the continuous oxidation of iron diffusing through lattice vacancies and the presence of oxygen at high concentration in the outer scale layers [31].

The increase in the oxidation temperature and duration increases the scale thickness. For very high oxidation temperatures and durations, a gap appears at the scale/metal interface limiting the diffusion of iron to form wüstite. This leads to the formation of thicker magnetite and hematite layers above wüstite. [18, 21].

As for the scale growth kinetics, the scale morphology for silicon alloyed steels is very dependent on silicon content and oxidation temperature.

For Si16 grade, wüstite and magnetite layers similar to those of Si00 are observed, but between steel and wüstite there is also an internal sub-layer composed of silicon-iron oxides. The variation of the internal sub-layer morphology with oxidation temperature is given on Fig.6a and Fig.7a. 
According to Raman and SEM analyses, between $950^{\circ} \mathrm{C}$ and $\sim 1180^{\circ} \mathrm{C}$ (melting point of $\mathrm{FeO}+\mathrm{Fe}_{2} \mathrm{SiO}_{4}$ eutectic) grains of fayalite appear in the wüstite matrix of the internal layer. Fayalite is clearly detected by Raman spectrometry due to its characteristic double peak at 810 and $840 \mathrm{~cm}^{-1}$ (Fig. 6b) [32, 33]. Above $1180^{\circ} \mathrm{C}$, a continuous layer of fayalite is observed at the steel/wüstite interface with some infiltrations at the grain boundaries of steel and wüstite layer (Fig. 7). This layer is formed at the melting of $\mathrm{FeO}+\mathrm{Fe}_{2} \mathrm{SiO}_{4}$ eutectic at these temperatures. Some wüstite small grains appear in the fayalite layer (Fig. 7). For long oxidation times, the presence of the thick fayalite layer leads to break-down at the steel/scale interface due to volume shrinkage during solidification and thermo mechanical stresses.

For Si32 sample, the long passivation period observed at $1000^{\circ} \mathrm{C}$ and $1100^{\circ} \mathrm{C}$ during scale growth produces discontinuous scale composed of islands surrounded by a very thin passivating layer. The islands are composed of an external curved wüstite and an internal curved wüstite matrix containing fayalite grains (Fig. 8). These islands can be formed after local rupture of the barrier layer and enhanced iron diffusion through defects or film grain boundaries [21].

To determine the nature of the passivation layer, XPS analysis was performed on the Si32 sample oxidized at $1100^{\circ} \mathrm{C}$ during 2 min corresponding to the beginning of passivating regime (Fig. 9). XPS survey spectrum performed at $45^{\circ}$ from spectrometer axis indicates the presence of iron, silicon, manganese, oxygen and carbon at the sample surface (Fig. 9a). On oxygen $(\mathrm{O} 1 \mathrm{~s})$ high resolution spectrum silicon oxide of $\mathrm{SiO}_{2}$ type and hydroxide phases are clearly distinguished (Fig. 9b). The iron and manganese oxides are also present on the sample surface, they are revealed by a peak at $529.5 \mathrm{eV}$ in Figure 9b. Silicon (Si2p) high resolution spectrum reveals three elementary components: two different oxide phases containing silicon and a metallic form of silicon. The first one of the oxide phases corresponds typically to the $\mathrm{SiO}_{2}[34]$ whereas the second one can be attributed to $\mathrm{SiO}_{\mathrm{x}}(\mathrm{x}<2)$ or fayalite $\left(\mathrm{Fe}_{2} \mathrm{SiO}_{4}\right)$.

XPS results are confirmed by SEM observations and Auger microanalysis of the sample surface (Fig. 10). Auger spectra performed in differentiated mode show silicon enrichment in smooth areas of the sample surface corresponding to the presence of silicon oxide film ( $\mathrm{Si}$ peak at $1619 \mathrm{eV}$ and $\mathrm{O}$ peak at $505 \mathrm{eV}$ in Fig. 10b). The presence of iron oxides can be seen on the surface of islands (Fe triplet transition at 598,651 and $703 \mathrm{eV}$ and $\mathrm{O}$ peak at $505 \mathrm{eV}$ in Fig. 10c). These results are in good agreement with the XPS conclusions suggesting the presence of a $\mathrm{SiO}_{2}$ layer at the surface in smooth areas between iron oxide islands. This also corroborates observations made in the kinetics study concerning the silicon oxide layer. Formed during the first instants of oxidation, it slows down the diffusion of iron and, consequently, the scale growth (passivation period). Nevertheless, the scale continues to grow during the passivation period, yet at a small rate, a consequence of the low diffusion coefficient of iron in silicon oxide. This diffusion can occur at the $\mathrm{SiO}_{2}$ layer defects such as grain boundaries leading to the formation of islands (Fig. 10a).

\section{Conclusions:}

In steel oxidations at high temperatures $\left(850-1200^{\circ} \mathrm{C}\right)$ in humid air $\left(15 \% \mathrm{H}_{2} \mathrm{O}\right)$ during a short time (15min), the addition of high amounts of silicon to steel (1.6 and 3.2\% wt) slows down drastically the scale growth for temperatures below $1177^{\circ} \mathrm{C}$ with the formation of a silica sub-layer at the beginning of oxidation. This passivation effect disappears with the formation of $\mathrm{FeO}-\mathrm{Fe}_{2} \mathrm{SiO}_{4}$ eutectic above $1177^{\circ} \mathrm{C}$ and the enhancement of $\mathrm{Fe}^{2+}$ diffusion. Silicon oxides are concentrated at the metal/scale interface and their morphology depends on the oxidation temperature. Fayalite grains in wüstite matrix appear between $900^{\circ} \mathrm{C}$ and $1100^{\circ} \mathrm{C}$ and continuous layer of fayalite-wüstite eutectic above $1177^{\circ} \mathrm{C}$. For silicon content of 
$3.2 \mathrm{wt} . \%$ the passivation effect is so high that the resulting scale is discontinuous with islands surrounded by a silica layer.

\section{Acknowledgments}

The authors are extremely grateful to the staff of ArcelorMittal Research (M.J. Cornu, F. Broquedis, G. Audo for XPS and Auger characterizations, M. Crocenzo for elaboration of steel samples, M. Picard for help in oxidation) and Laboratoire Interfaces et Systèmes Electrochimiques (F. Pillier for SEM observation). 


\section{References}

[1] R. Chen, W. Yuen, ISIJ international, 45 (2005) 52-59.

[2] M. Danielewski, Materials Park, (2003).

[3] P.H. Bolt, Steel research international, 75 (2004) 399-404.

[4] L. Holappa, V. Ollilainen, W. Kasprzak, Journal of Materials Processing Technology, 109 (2001) 78-82.

[5] H.-W. Hsu, W.-T. Tsai, Materials chemistry and physics, 64 (2000) 147-155.

[6] T. Ros-Yanez, Y. Houbaert, O. Fischer, J. Schneider, Journal of materials processing technology, 143 (2003) 916-921.

[7] S. Basu, G. Yurek, Oxidation of Metals, 36 (1991) 281-315.

[8] R. Chen, W. Yuen, Oxidation of Metals, 57 (2002) 53-79.

[9] R.Y. Chen, W. Yuen, Materials science forum, Trans Tech Publ, 2006, pp. 77-86.

[10] R.Y. Chen, W.Y. Yuen, Oxidation of Metals, 70 (2008) 39-68.

[11] L. Suárez, P. Rodríguez-Calvillo, Y. Houbaert, R. Colás, Corrosion Science, 52 (2010) 2044-2049.

[12] A. Atkinson, Corrosion Science, 22 (1982) 87-102.

[13] T. Adachi, G. Meier, Oxidation of Metals, 27 (1987) 347-366.

[14] D. Genève, Institut National Polytechnique de Lorraine Thesis Collection, (1996).

[15] E.M. Levin, C.R. Robbins, H.F. MacMurdie, K. Reser, N.b.o. standards, A.C. Society, NBS., Phase Diagrams for Ceramists, 1969.

[16] J. Bénard, J. Bardolle, L'oxydation des métaux, Gauthier-Villars, 1964.

[17] C. Wagner, Journal of the electrochemical Society, 99 (1952) 369-380.

[18] J. Paidassi, Acta Metallurgica, 6 (1958) 184-194.

[19] S. Mrowec, A. Stokłosa, Oxidation of Metals, 8 (1974) 379-391.

[20] E. Ahtoy, Thesis Collection, Université de Grenoble, 2010.

[21] Y.-L. Yang, C.-H. Yang, S.-N. Lin, C.-H. Chen, W.-T. Tsai, Materials Chemistry and Physics, 112 (2008) 566-571.

[22] C. Tuck, Corrosion Science, 5 (1965) 631-643.

[23] L. Yang, C.Y. Chien, G. Derge, The Journal of Chemical Physics, 30 (1959) 1627-1627.

[24] Y. Li, R.J. Fruehan, J.A. Lucas, G.R. Belton, Metallurgical and Materials Transactions B, 31 (2000) 1059-1068.

[25] Y. Sayadyaghoubi, S. Sun, S. Jahanshahi, Metallurgical and Materials Transactions B, 26 (1995) 795-802.

[26] P. Wang, Y. Feng, W. Roth, J. Corbett, Journal of non-crystalline solids, 104 (1988) 8184.

[27] R. Chen, W. Yeun, Oxidation of Metals, 59 (2003) 433-468.

[28] R. Chen, W. Yuen, Oxidation of Metals, 53 (2000) 539-560.

[29] A. Chattopadhyay, N. Bandyopadhyay, A. Das, M. Panigrahi, Scripta materialia, 52 (2005) 211-215.

[30] M. Hanesch, Geophysical Journal International, 177 (2009) 941-948.

[31] H. Abuluwefa, R. Guthrie, J. Root, F. Ajersch, Metallurgical and Materials Transactions B, 27 (1996) 993-997.

[32] A. Guedes, B. Valentim, A. Prieto, A. Sanz, D. Flores, F. Noronha, International Journal of Coal Geology, 73 (2008) 359-370.

[33] B. Kolesov, C. Geiger, Physics and chemistry of minerals, 31 (2004) 155-161.

[34] C.D. Wagner, G.E. Muilenberg, Handbook of x-ray photoelectron spectroscopy: a reference book of standard data for use in x-ray photoelectron spectroscopy, Physical Electronics Division, Perkin-Elmer Corp., 1979. 


\section{Figures captions:}

Fig. 1. Mass gain of Si00 during oxidation in $15 \%$ humid air at temperatures $900-1200^{\circ} \mathrm{C}$.

Fig. 2. Mass gain of Si16 during oxidation in $15 \%$ humid air at temperatures $900-1200^{\circ} \mathrm{C}$ (a) with a zoom on the passivation period (b).

Fig. 3. Mass gain of Si32 during oxidation in $15 \%$ humid air at temperatures $900-1200^{\circ} \mathrm{C}$ (a) with a zoom on temperatures $\leq 1100^{\circ} \mathrm{C}(\mathrm{b})$.

Fig. 4. Effect of Si content and temperature on final mass change after oxidation in $15 \%$ humid air during 15 minutes.

Fig. 5. (a) Cross-section SEM micrograph of Si00 after oxidation at $850^{\circ} \mathrm{C}$ in $15 \%$ humid air during 15 minutes with (b) Raman spectra of its scale phases: hematite external surface, magnetite layer and wüstite layer.

Fig. 6. (a) Cross-section SEM micrograph of Si16 oxidized at $1100^{\circ} \mathrm{C}$ in $15 \%$ humid air during 15 minutes with a zoom on fayalite-wüsitite mixture layer. (b) Raman spectrum of fayalite grains in wüstite.

Fig. 7. (a) Cross-section SEM micrograph of Sil6 oxidized at $1200^{\circ} \mathrm{C}$ in $15 \%$ humid air during 1 minute with a zoom on fayalite layer. (b) Raman spectrum of fayalite layer with small wüstite grains.

Fig. 8. Cross-section SEM micrograph of Si32 oxidized at $1100^{\circ} \mathrm{C}$ in $15 \%$ humid air during 15 minutes.

Fig. 9. XPS analysis of Si32 sample surface after 2 minutes of oxidation at $1100^{\circ} \mathrm{C}$ in $15 \%$ humid air: $45^{\circ}$ survey (a), high resolution XPS spectra of O 1s (b) and Si $2 p$ (c).

Fig. 10. (a) SEM micrograph of Si32 sample surface after 2 minutes of oxidation at $1100^{\circ} \mathrm{C}$ in $15 \%$ humid air with Auger spectra in differentiated mode performed in the smooth areas of the surface (b) and on iron oxide islands (c). 
Tables

\begin{tabular}{cccccccccc}
\hline Sample & \multicolumn{8}{c}{ Elements (wt.\%) } \\
\cline { 2 - 10 } & $\mathrm{C}$ & $\mathrm{Si}$ & $\mathrm{Mn}$ & $\mathrm{P}$ & $\mathrm{Cr}$ & $\mathrm{Ni}$ & $\mathrm{Cu}$ & $\mathrm{N}$ & $\mathrm{Fe}$ \\
\hline Si00 & 0.04 & 0.02 & 0.19 & 0.01 & 0.025 & 0.017 & 0.025 & 0.01 & Balance \\
$\mathrm{Si} 16$ & 0.04 & 1.55 & 0.19 & 0.01 & 0.025 & 0.017 & 0.025 & 0.01 & Balance \\
$\mathrm{Si} 32$ & 0.04 & 3.25 & 0.19 & 0.01 & 0.025 & 0.017 & 0.025 & 0.01 & Balance \\
\hline
\end{tabular}

Table 1 Chemical composition of the three steel grades with optical emission spectroscopy (OES)

\section{(a)}

\begin{tabular}{rrrr}
\hline T\Sample & Si00 & Si16 & Si32 \\
\hline $900^{\circ} \mathrm{C}$ & 8.50 & 4.69 & 1.60 \\
$1000^{\circ} \mathrm{C}$ & 14.98 & 3.95 & 1.55 \\
$1100^{\circ} \mathrm{C}$ & 19.13 & 1.88 & 1.50 \\
$1200^{\circ} \mathrm{C}$ & 20.55 & 28.31 & 32.60 \\
\hline (b) & & & \\
\hline $\mathrm{T} \backslash$ Sample & Si00 & Si16 & Si32 \\
\hline $900^{\circ} \mathrm{C}$ & 10.50 & 7.18 & 1.50 \\
$1000^{\circ} \mathrm{C}$ & 47.46 & 14.98 & 0.11 \\
$1100^{\circ} \mathrm{C}$ & 88.00 & 84.58 & 0.09 \\
$1200^{\circ} \mathrm{C}$ & 238.00 & 460.94 & 975.90 \\
\hline
\end{tabular}

Table 2: Oxidation kinetics parameters: (a) $k_{l}\left(\mathrm{mg} \mathrm{cm} \mathrm{cm}^{-2}\right)$ and (b) $k_{p}\left(\mathrm{mg}^{2} \mathrm{~cm}^{-4} \mathrm{~min}^{-1}\right)$

\begin{tabular}{ccrr}
\hline Element (at. \%) & \multicolumn{3}{l}{ Phase } \\
& Magnetite & Wüstite & Fayalite \\
\cline { 2 - 4 } Fe & 43.6 & 49.4 & 35.0 \\
$\mathrm{O}$ & 56.4 & 50.6 & 48.9 \\
$\mathrm{Si}$ & & & 16.1 \\
\hline
\end{tabular}

Table 3: Chemical composition of scale phases with EDS 


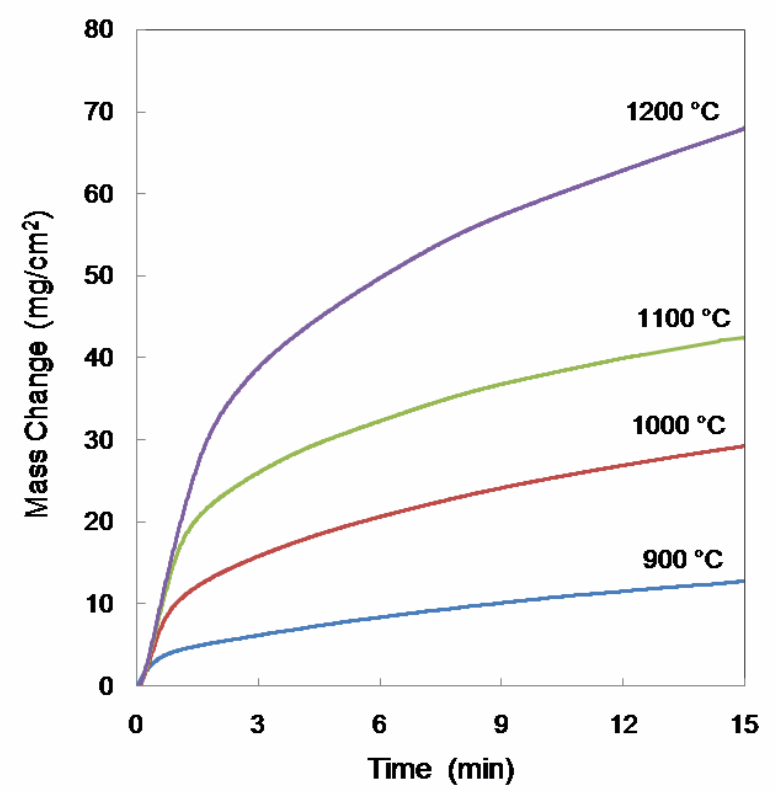

Fig. 1.

(a) 


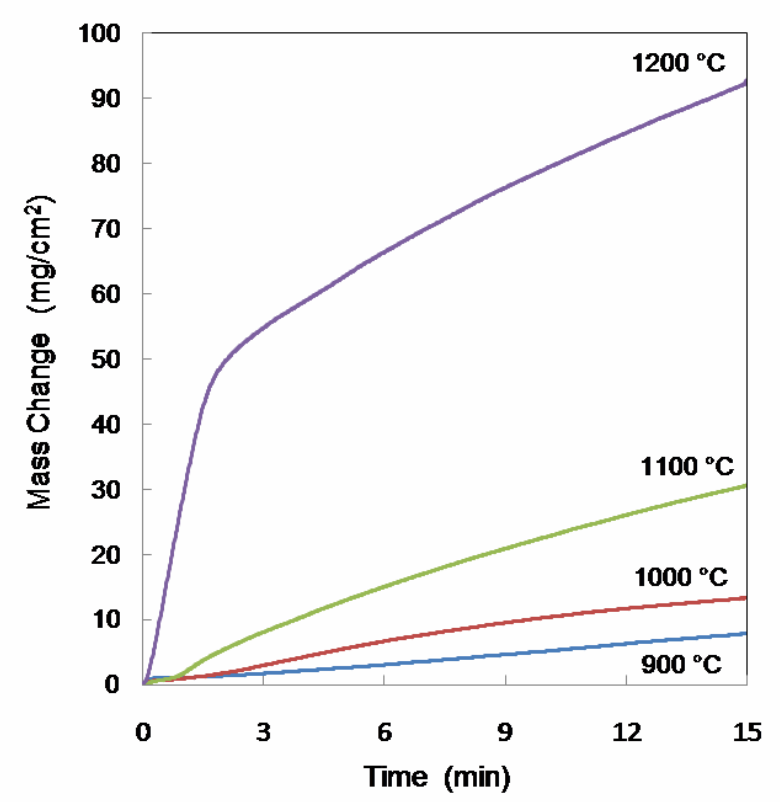

(b)

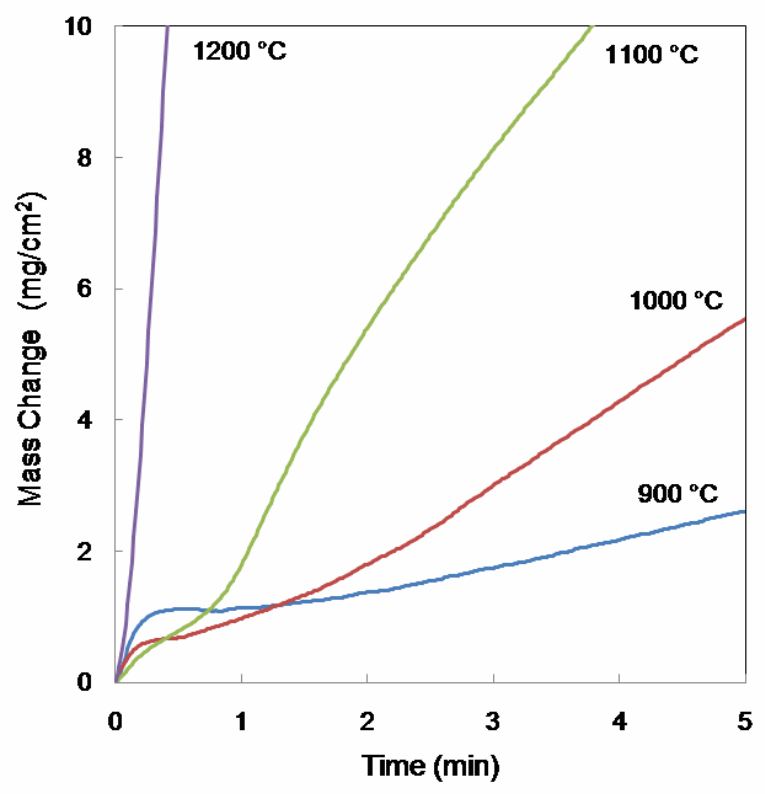

Fig. 2.

(a) 


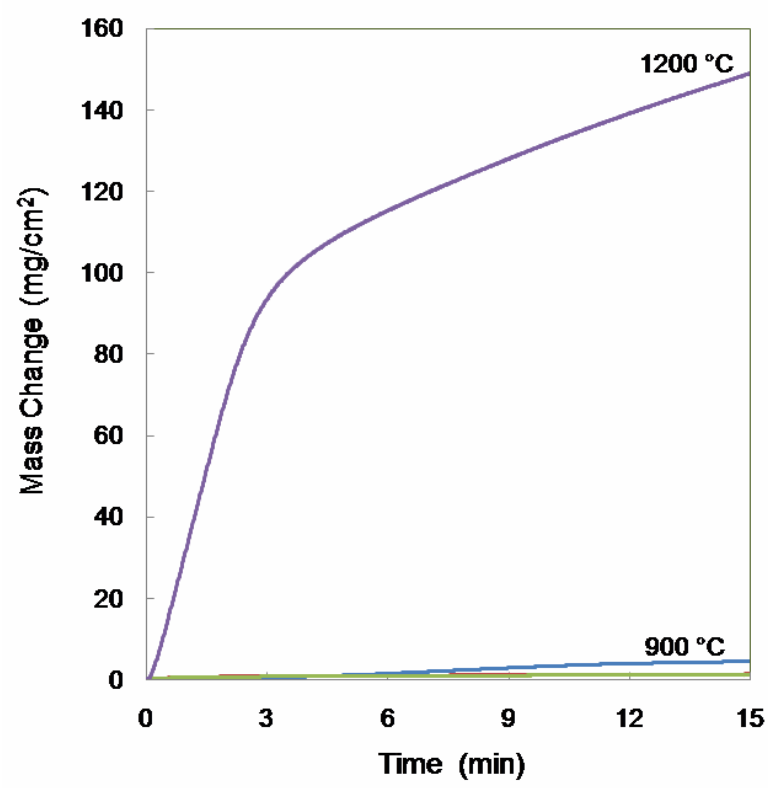

(b)

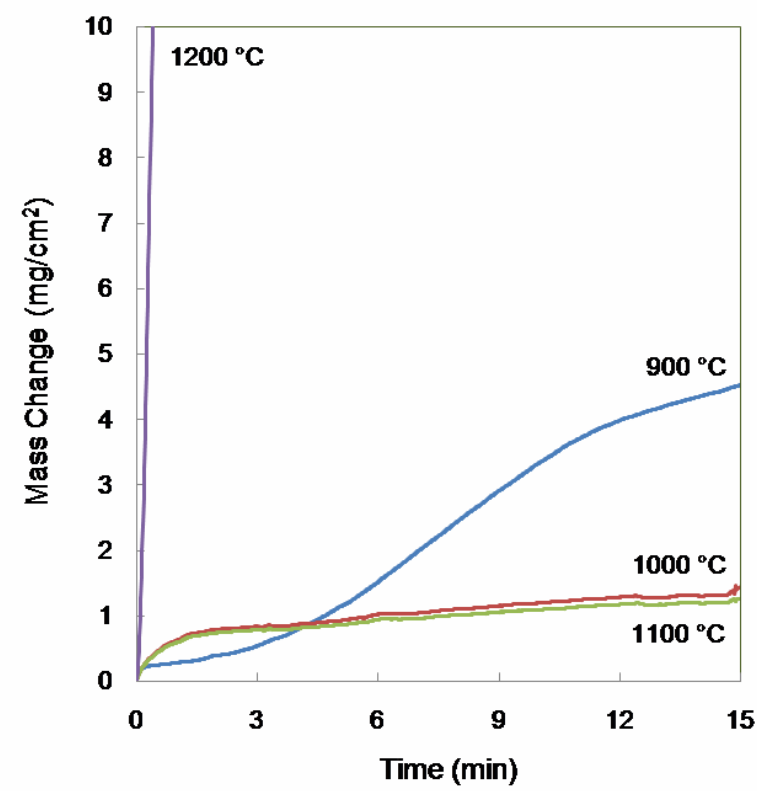

Fig. 3. 


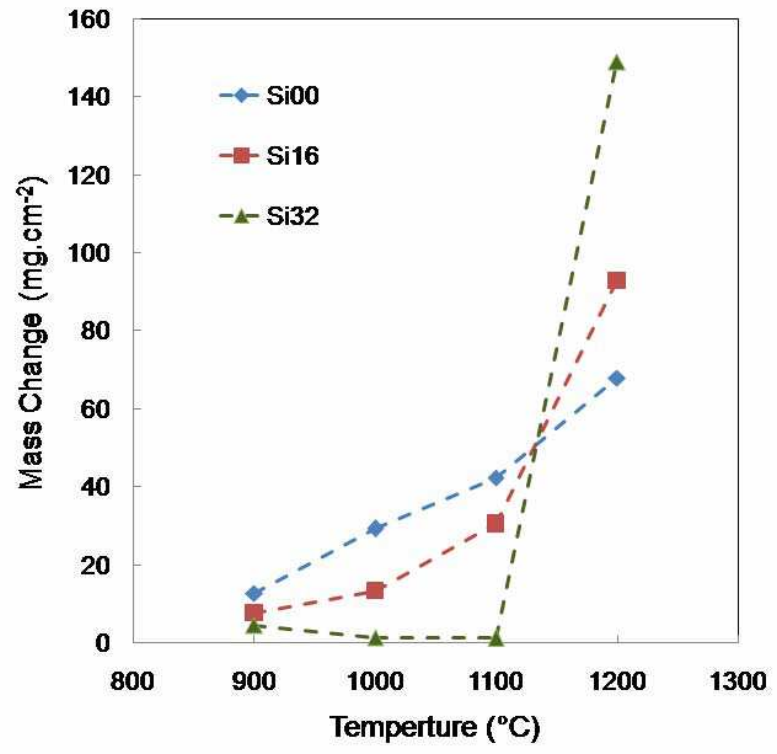

Fig. 4. 
(a)

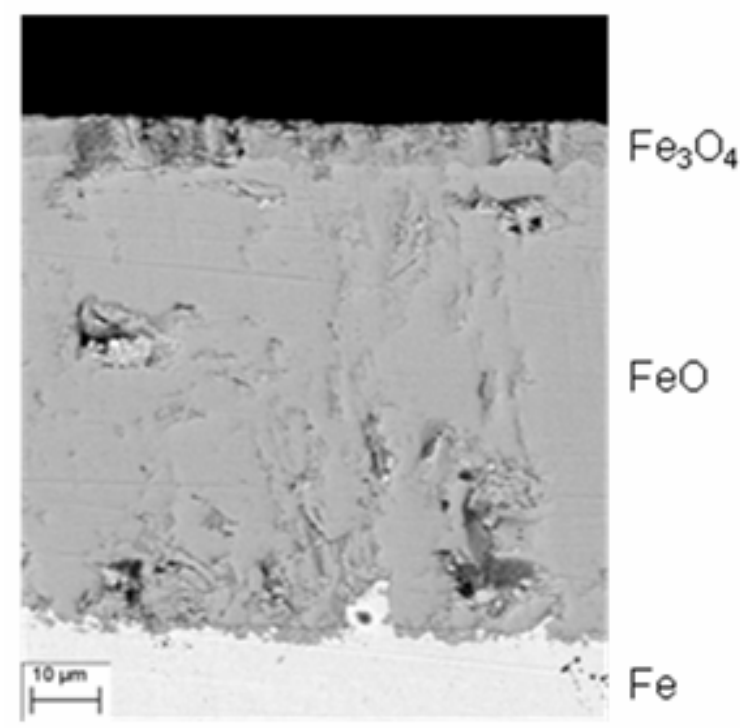

(b)

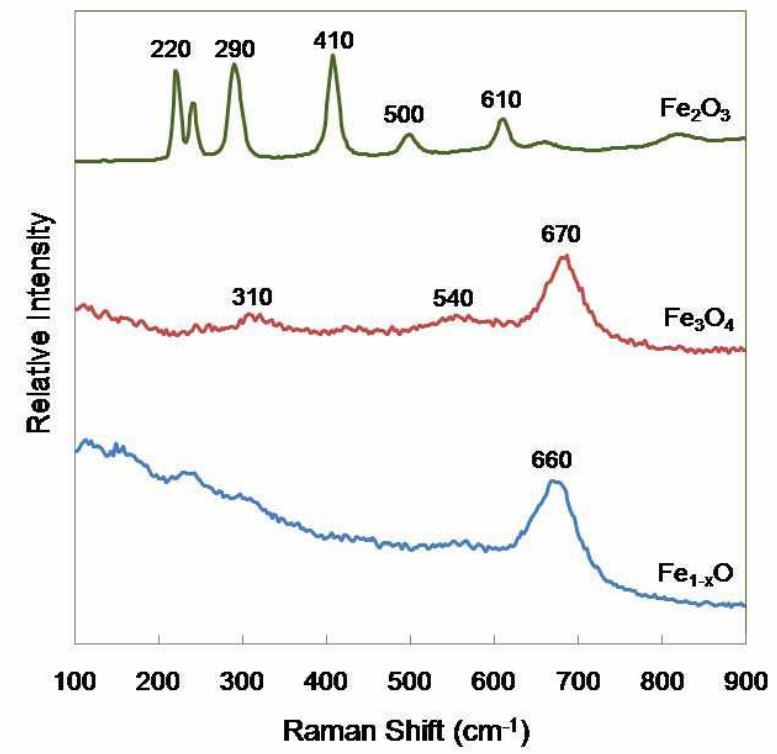

Fig. 5. 
(a)

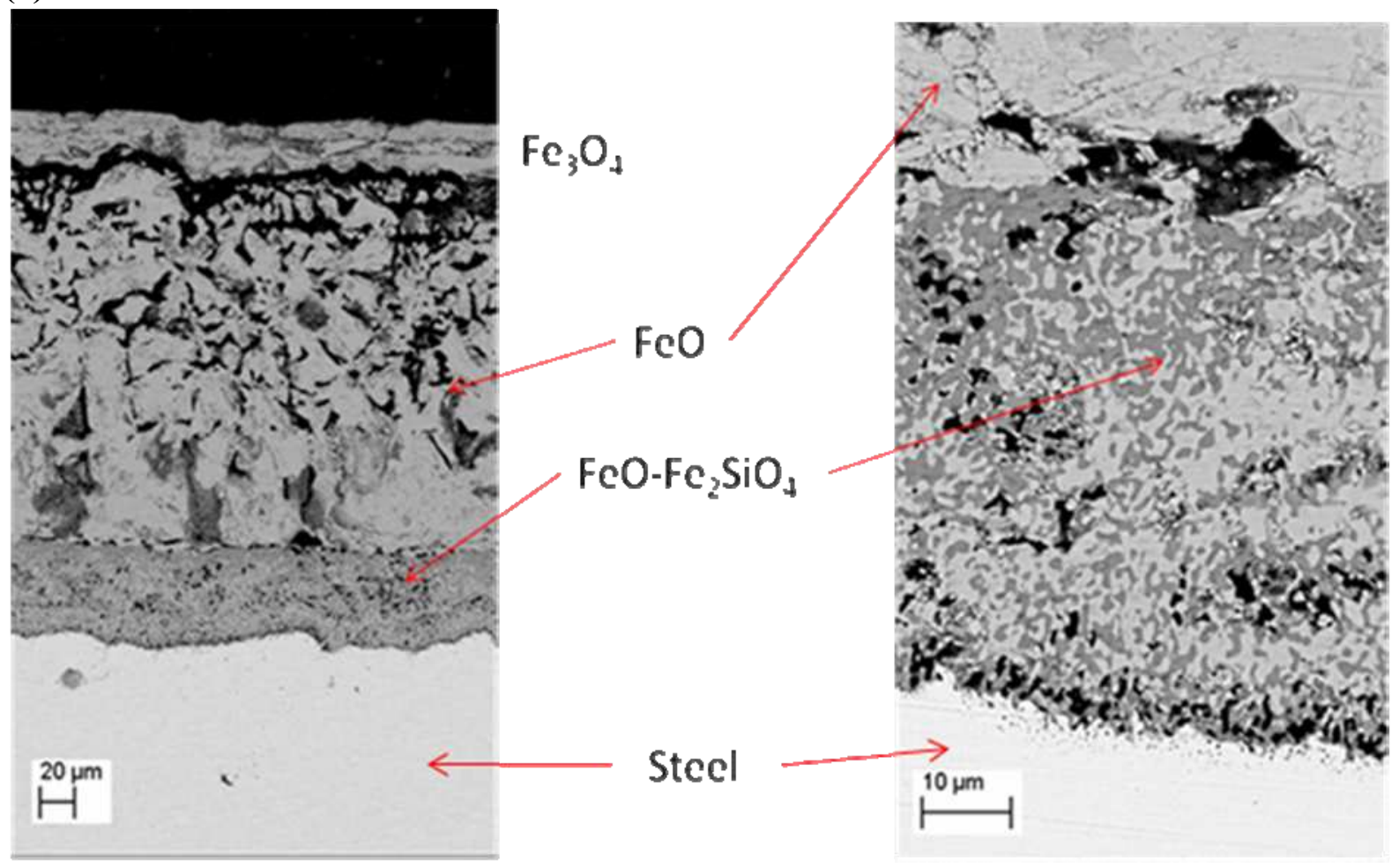

(b)

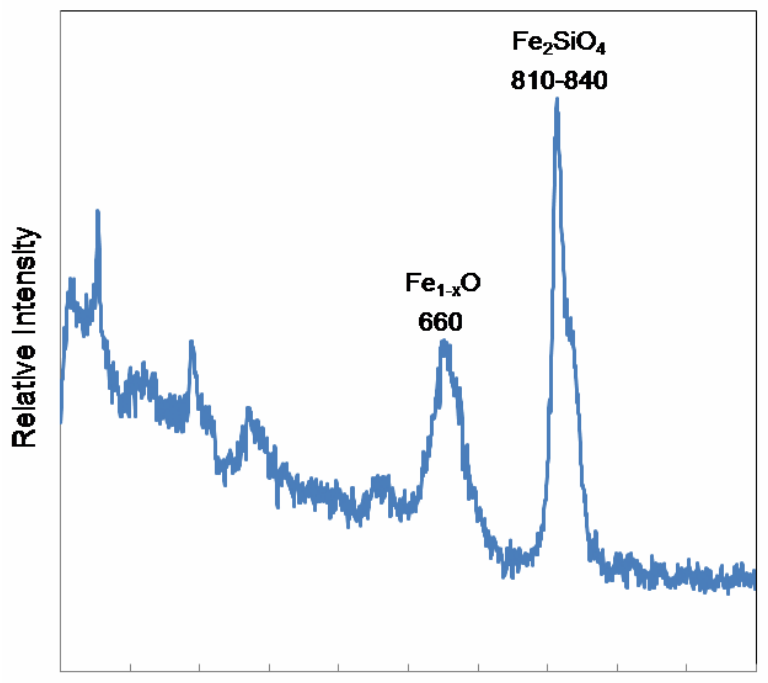

$\begin{array}{lllllllllll}100 & 200 & 300 & 400 & 500 & 600 & 700 & 800 & 900 & 1000 & 1100\end{array}$ Raman Shift $\left(\mathrm{cm}^{-1}\right)$

Fig. 6. 
(a)

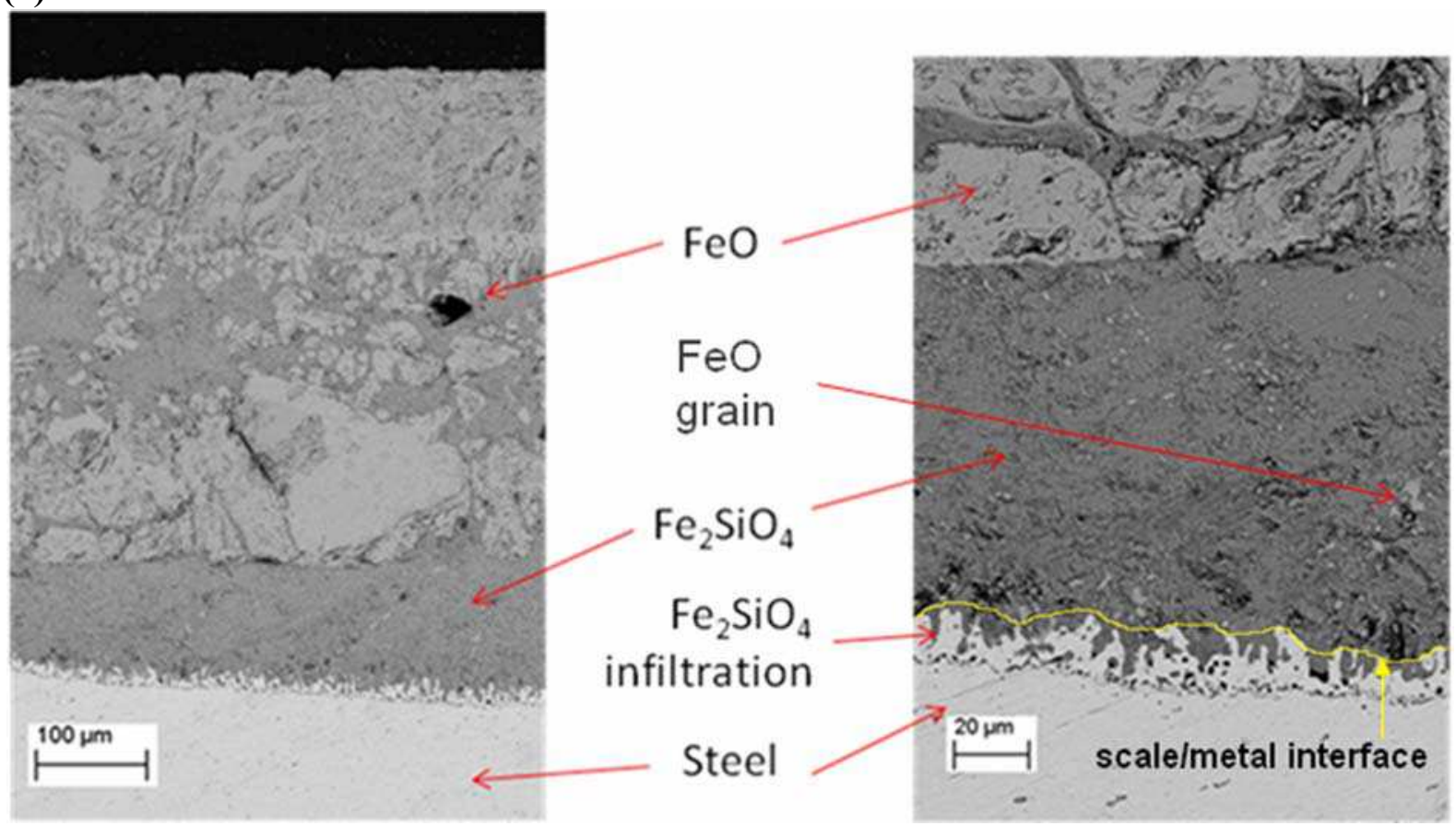

(b)

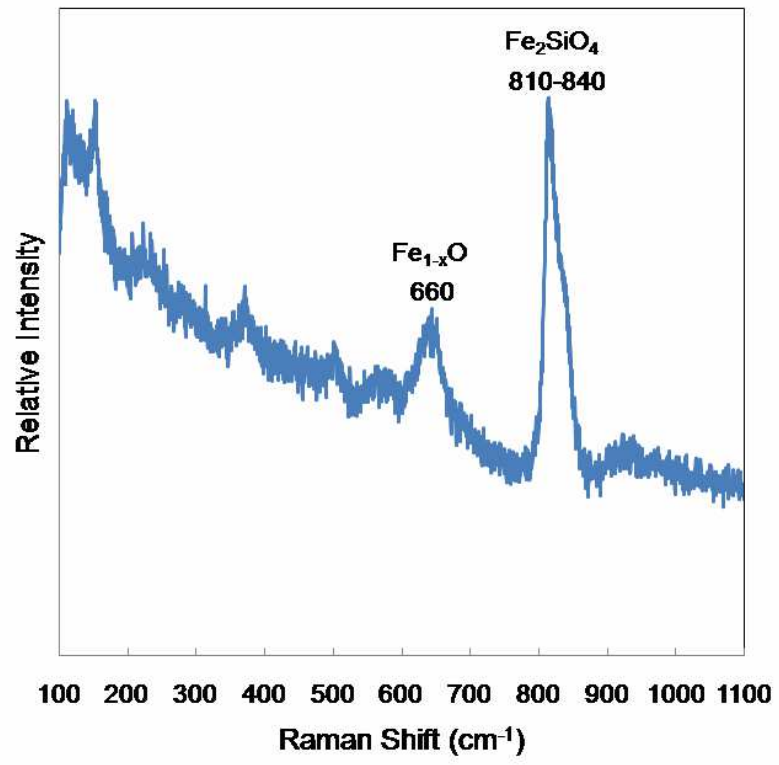

Fig. 7. 


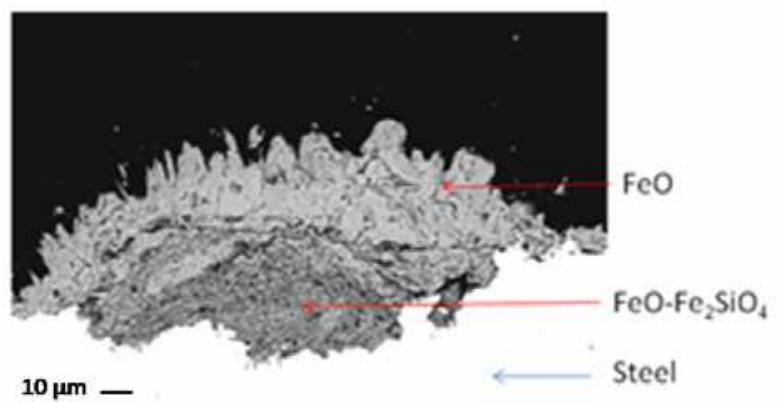

Fig. 8. 
(a)

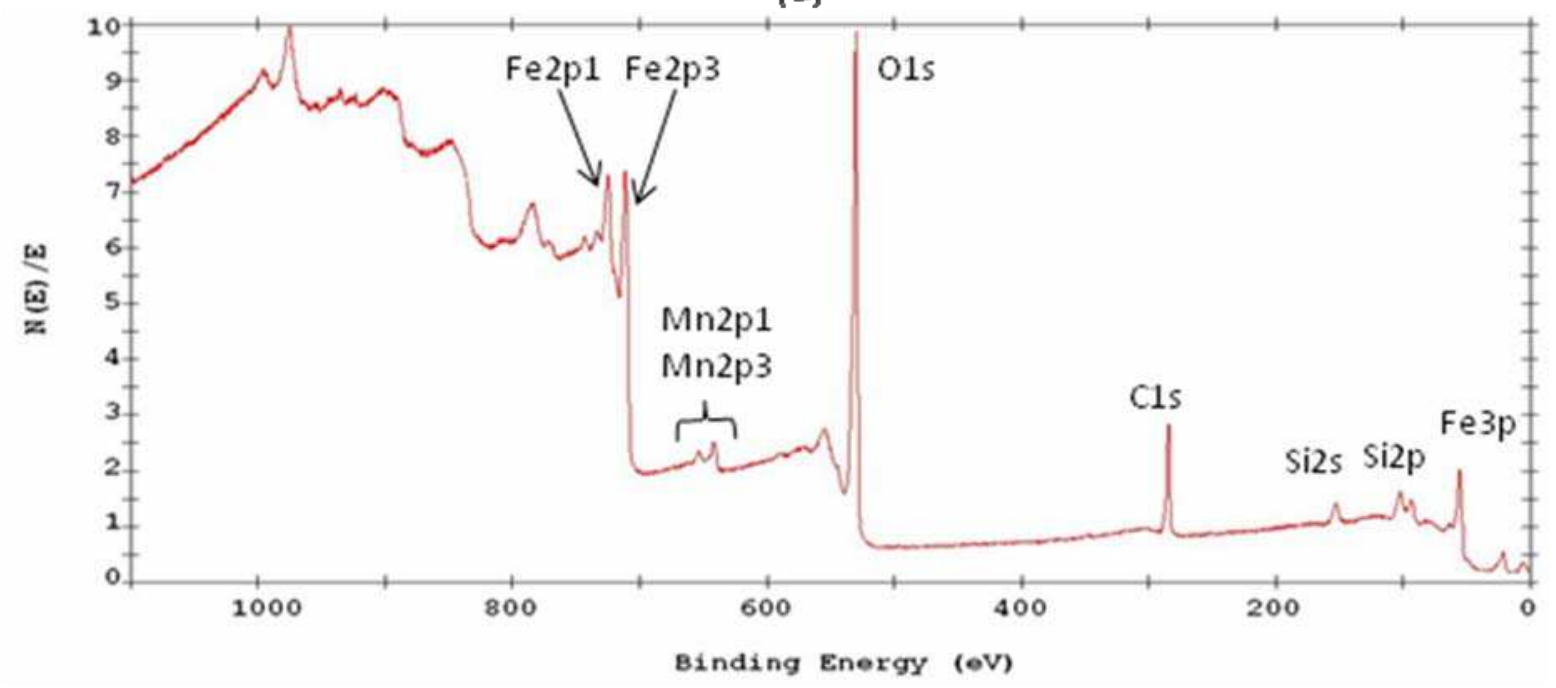

(b)

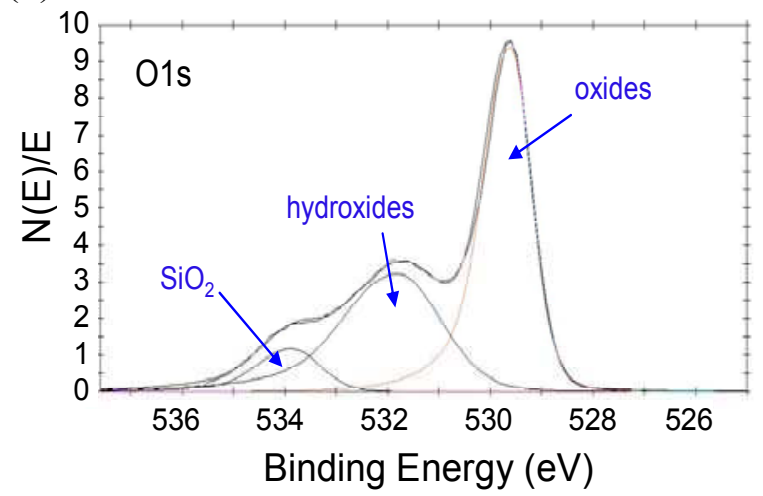

(c)

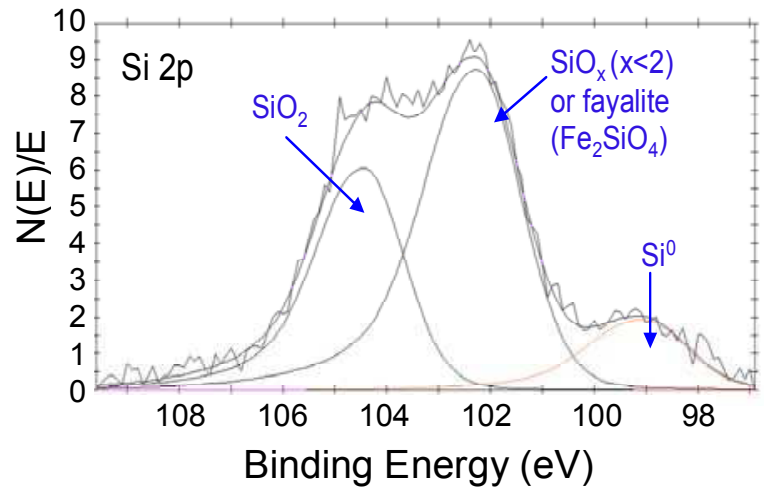

Fig. 9. 
(b)

(a)

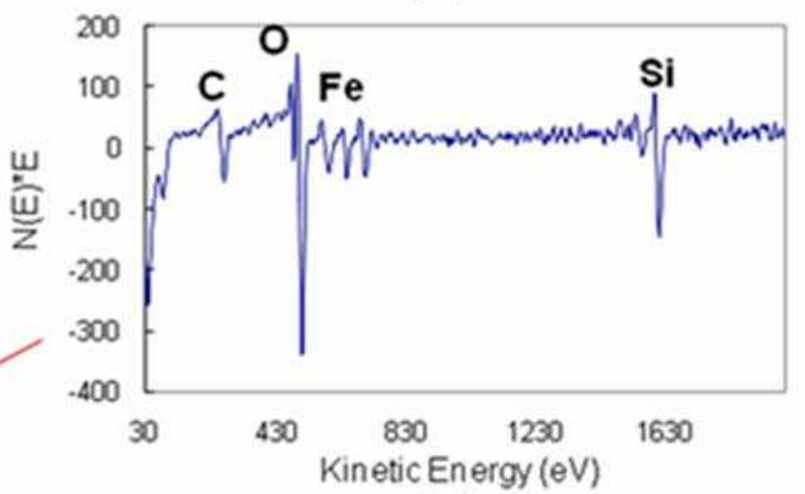

(c)
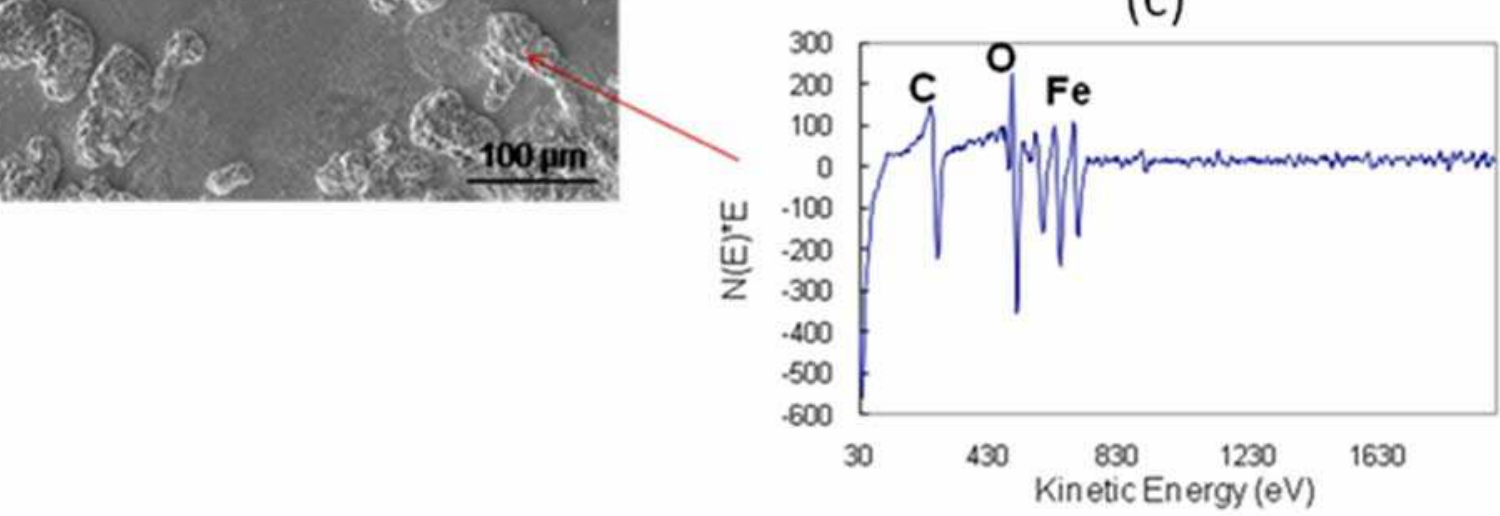

Fig. 10 